Article

\title{
Applicability of Transaction Cost Economics to Understanding Organizational Structures in Solidarity-Based Food Systems in Germany
}

\author{
Laura A. Carlson *(i) and Vera Bitsch $(\mathbb{D}$ \\ Chair Group of Economics of Horticulture and Landscaping, School of Management and School of Life Sciences \\ Weihenstephan, Technical University of Munich, Alte Akademie 16, 85354 Freising, Germany; bitsch@tum.de \\ * Correspondence: laura.carlson@tum.de; Tel.: +49-08161-71-2540
}

Received: 15 December 2018; Accepted: 15 February 2019; Published: 19 February 2019

check for updates

\begin{abstract}
In response to consumer concerns about sustainability of food production and distribution systems, and the difficulties many agricultural producers face to self-sustain while providing the quality of products consumers desire, alternatives to market-based exchange are developing. Solidarity-based food systems (SFS) based on relationships of mutual trust, dependency and support between consumers and producers are an example. SFS are designed to insulate producers from market pressures and alleviate consumers' mistrust in market-based mechanisms. A network of SFS has formed in Germany under the name Solidarische Landwirtschaft (Solawi). Theories based on economic principles that help explain the way alternatives to market-based transactions in agriculture are organized are still lacking. The article suggests Transaction Cost Economics (TCE) as helpful to gain a better understanding of how these organizations form and function. The governance structures Solawis create are considered hybrid organizations according to TCE. Qualitative research methods are used to generate detailed accounts of the governance structures of four Solawis and the reasons behind the decisions of individual actors to participate. Effectiveness of TCE in evaluating these structures is analyzed. Based on the results, the concept of transaction benefits is suggested as a potential augmentation of TCE to improve its applicability to SFS.
\end{abstract}

Keywords: Community Supported Agriculture (CSA); consumer-producer relationships; new institutional economics (NIE); short supply chains; vertical coordination

\section{Introduction}

New organizational models in agricultural and food supply systems focused on locally grown and distributed food and/or direct connections between producers and consumers are increasing in importance worldwide [1]. This development stems in part from perceptions among consumers and producers that agricultural supply chains as they are currently constructed are socially, economically, and environmentally unsustainable [2]. Sustainability initiatives and certification schemes are perceived as having failed to address "wicked problems" in agriculture such as inadequate financial compensation and poor working conditions for producers and workers, and production methods with detrimental impacts on the environment [3].

All of these factors have contributed to the development of solidarity-based food systems. In solidarity-based exchange systems, producers and consumers recognize their interdependence, and attempt to create new arrangements for doing business that are mutually supportive and insulated from the problems of market exchange [4]. Rather than being focused on the accumulation of capital or profit-maximization, they emphasize the satisfaction of basic human needs-both physical and social [5]. In the field of agriculture and food, systems that emphasize direct relationships between 
food producers and consumers are commonly referred to as alternative food networks (AFNs) [1], but are not necessarily explicitly grounded in the concept of solidarity. Some examples of AFNs that are explicitly based on solidarity principles have developed under various names in different geographic regions. Examples include (but are not limited to) the Teikei movement in Japan [6], Community Supported Agriculture (CSA) in English-speaking countries [7], and solidarity-based agriculture (Solidarische Landwirtschaft or Solawi) in Germany [8]. All share the common goal of creating new systems of governing the exchange of agricultural products that make use of personal resources of consumers to support sustainability in the production and/or distribution of food.

Supporting more sustainable production and distribution systems by allowing participants "to construct new social and economic institutions for governance which value the social and environmental aspects of wellbeing alongside the economic" is becoming increasingly important to governments and policy-makers worldwide [9] (p. 385). However, much modern economic research and policy is still based on theoretical principles that focus on the price mechanism and the extent to which market intervention from public institutions is warranted. Therefore, it does not necessarily lend itself well to understanding exchange relationships that specifically incorporate non-monetary value. Transaction Cost Economics (TCE) in large part deals with the organization of exchange that occurs outside the market [10-13], and thus appears to have potential to form the basis for developing innovative economic theories more applicable to new social and economic governance structures designed to alleviate the problems of the market mechanism.

According to TCE theory, transaction costs are costs that arise due to organizational challenges within firms (such as communication and coordination) and/or the costs of securing and enforcing inter-organizational agreements that grow out of the inherently incomplete nature of contracts $[10,11]$. TCE contends that the decisions to create governance arrangements that place transactions outside the market are made based on their perceived costs (i.e., the type and amount of resource investments they require) relative to those that occur in simple market exchanges. While originally focused on a decision between two binary choices—-market or hierarchy (i.e., the firm) - TCE has gradually evolved to recognize a wide variety of potential arrangements that fall somewhere along a continuum between the two $[13,14]$. In between these two extremes are hybrid models, in which the organizational structure is dependent on the nature of the transactions they govern. Common examples of hybrids that have been analyzed using TCE concepts are franchising, long-term contracting and production or service cooperatives [15]. Such analyses have examined organizational models in a wide range of trade situations, sectors and industries [15].

According to TCE, the nature of exchange mechanisms is largely determined by three main interrelated factors: uncertainty, asset specificity, and frequency of interaction [10]. Uncertainty in exchange relationships stems from two main sources-bounded rationality and opportunism [10]. Bounded rationality refers to the inability of individual parties to an exchange to process all available information in order to ensure that opportunism does not occur. Opportunism refers to the risk that one party will take advantage of information asymmetries to draw benefits for itself to the disadvantage of the other party [10]. Both problems contribute to uncertainty, which can be minimized by frequent interactions between buyers and sellers that serve to provide information about both the product being purchased (or sold) and the party purchasing (or selling) the product $[12,16]$. The anonymity of the market mechanism does not serve the purpose of information transmission and gathering well. Therefore, many buyers and sellers choose to cooperate in a series of repeated transactions to gain more information about one another and the products and services they wish to exchange to ensure the highest possible aggregate gains [12]. The potential benefits of such arrangements (in relationship to the associated costs) are greater in situations where specialized products are exchanged, resulting in situations that require credible commitments [16] such as the creation of relationship-specific capital [12].

Sustainably produced agricultural products can be seen as specialized products that require investment in relationship-specific capital, thus suggesting the applicability of TCE in evaluating efforts 
to create organizational structures that support more sustainable agricultural production systems. Although TCE has seldom been used to examine organizational arrangements in agriculture [15], some authors have used elements of TCE theory to help explain results of analyses of existing governance structures. Hagedorn et al. used TCE concepts in evaluating the results of comparative qualitative case studies of agricultural service cooperatives in Central and East European Countries [17]. They found the key factors contributing to success of the service cooperatives examined were the presence of leaders with advanced communication skills and extensive connections in the region, the need for and ability to use these skills to create trust among cooperative participants, and market conditions that made the services of the cooperative necessary for producers. Traversac et al. used concepts from TCE theory to help explain results of a discrete choice model of the French wine industry [18]. Contrary to expectations, despite existing public-private institutional structures to ensure quality of wines of Protected Designation of Origin (PDO), producers of PDO were found to be more likely than other producers to integrate forward and market their wines directly. Although the decision to use direct marketing appears inefficient in TCE terms, the authors posit that it might be attributable to producer perceptions that existing institutions fail to ensure PDO quality standards are met. Direct marketing allows producers to have more control over quality assurance, and thus, to protect the brand value of geographic indications. Masten also points out that increased control is the main advantage of internalizing production and distribution stages that could be accomplished more efficiently through economies of scale inherent to specialization [15]. Therefore, certain necessary conditions must be present in the market for a specialized product to justify integration of marketing and distribution by producers. Further, once these conditions are present, individuals with specialized knowledge, skills and expertise must be present, willing and able to invest relationship-specific capital. This involves committing personal resources to create and manage new governance structures designed to create trust in the product by exercising controls that help ensure that trust is justified. The level of control realized by these efforts is determined by the nature of the contract that exists between a producer and the supplier of a good or service.

The German Solawi movement took steps early on to promote their own standards of quality through establishment of an organizational network [19]. By legally protecting the use of the Solawi name, the network founders hoped to prevent Solawi from suffering the same commercialization process they perceive to have occurred in organic agriculture. Organic agriculture (in its modern form) began as a reaction to similar sustainability concerns [20], but-in the eyes of some critics-rapidly became commercialized and corporatized, and its key concepts substantially weakened [21].

Enterprises using the Solawi name are expected to adhere to a set of eight statutes, designed to institutionalize key concepts such as sharing financial risk and responsibility and distributing generated value equitably among Solawi participants. Relationships between consumers and producers based on trust and communication are developed through a system of transparent co-financing of farm operations, in exchange for an equal share in the harvest. Self-determined production methods that protect water, soil and other natural resources demonstrate solidarity with non-participants, with other forms of life, with inhabitants of other nations and with future generations. As these statutes do not prescribe specific formal structures, each Solawi is free to choose specific aspects of its production methods that meet the standards described above, and create its own governance structures for production and distribution. Therefore, flexibility for local actors to construct systems that meet their own needs and unique social, economic, political and natural environments is built into the Solawi model.

The objectives of this paper are, to illustrate the variety of unique organizational arrangements Solawis create; to characterize the specialized product Solawi participants wish to produce (and/or consume); and to analyze the degree to which the process of creating relationship-specific capital serves to limit the perceived costs of exchange among participants. Key concepts of TCE are compared to the events and processes described by Solawi participants as important in making the decision to form 
Solawis and in choosing particular organizational structures. Potential changes and augmentations to TCE to make it more applicable to solidarity-based economic arrangements are suggested.

\section{Materials and Methods}

Qualitative research methods are widely thought to be effective in understanding social phenomena, and are particularly valuable both in gaining understanding in new areas of research and expanding existing theory [22]. Grounded Theory analysis is one such qualitative method that seeks to understand the lived experience of participants in a given socially constructed system through an iterative, abductive process of data collection and analysis [23]. Rich qualitative data obtained from a number of sources are compared to one another in order to identify broader conceptual categories based on the theoretical sensitivity of the researcher [23]. As conceptual categories begin to emerge from comparison of the data collected, common themes and inconsistencies are identified. Further data collection and subsequent analysis is then undertaken to elaborate on those common themes and identify the source of perceived inconsistencies. Constant comparison of the data from which those themes emerge helps combine the themes identified into a more abstract conceptual frame that encompasses the most important phenomena at work in a given situation (see Appendix A for an example). This conceptual frame can then be compared to existing theories and frameworks to evaluate their applicability in the context under investigation, and to improve or expand upon them.

Data collection for this analysis took place from June of 2017 through December 2018. Initial data collection was conducted using participant observation at a seminar offered by an independent party seeking to educate participants on key sustainability problems in food and agriculture systems. The seminar took place on the premises of a Solawi, and included a visit to a second Solawi and two other food-related initiatives. Initial analysis of the data collected there led to the realization that the concept of solidarity was an important element in all initiatives, but was more explicitly operationalized in the Solawi concept. The inherent complexity of the Solawi system, the foundation of solidarity on which it is based, and the variety of ways the concept is operationalized led to it being chosen as the subject for more intensive investigation. A subsequent visit to the annual membership meeting of the Solawi network yielded additional data-again collected through participant observation. Analysis of field notes from these two events led to a greater understanding of the potential breadth and depth of governance structures in Solawis. At a second meeting of the Solawi network, in-depth interviews with Solawi participants and consultants from the Solawi network were conducted. During subsequent visits to the production sites of the four Solawis selected as case studies, additional interviews were conducted (Table 1).

Table 1. Summary of data types by organization.

\begin{tabular}{lccccc}
\hline Organization & $\begin{array}{c}\text { In-Depth } \\
\text { Interviews }\end{array}$ & $\begin{array}{c}\text { Field Notes } \\
\text { from Production } \\
\text { Site Visits }\end{array}$ & $\begin{array}{c}\text { Field Notes from } \\
\text { Workday at } \\
\text { Production } \\
\text { Site/Members } \\
\text { Present }\end{array}$ & $\begin{array}{c}\text { Field Notes from } \\
\text { Member } \\
\text { Meetings/Number } \\
\text { of Meetings; } \\
\text { Members Present }\end{array}$ & Archival Data \\
\hline SOLAWI 1 & 5 & 2 & - & - & yes \\
SOLAWI 2 & 1 & 2 & 5 & - & yes \\
SOLAWI 3 & 1 & 1 & - & $2 ; 40,55$ & yes \\
SOLAWI 4 & 3 & 1 & 25 & $1 ; 50$ & yes \\
SOLAWI & 7 & $\mathrm{n} / \mathrm{a}$ & $\mathrm{n} / \mathrm{a}$ & $100(25 *), 100(30 *)$ & yes \\
network & 7 & & & & \\
\hline
\end{tabular}

$\mathrm{n} / \mathrm{a}=$ not applicable; ${ }^{*}=$ Number of Solawis represented at each network meeting. Source: Authors' own compilations.

All interviews were conducted based on a general interview guide (Appendix B) that was adjusted as the interview process progressed with questions based on the particular role of each interviewee in relation to Solawi, and themes identified during the analysis of previously collected data. Some questions central to this research were not asked directly, to not impose the conceptual thinking 
of the interviewer on the interviewees. For example, details on the interviewees' understanding of solidarity were pursued only after an interviewee had brought up terms such as community or solidarity.

Additional data were obtained from documents, such as copies of membership agreements and bylaws, obtained either directly from interviewees or from the websites of the organizations. Attendance at a third meeting of the Solawi network as well as membership meetings of two of the Solawis helped to further inform the analysis (Table 1). Several interviewees were contacted again for additional short phone interviews to clarify questions encountered during the process of analysis, and to confirm the accuracy of the representations. Throughout the data collection process, coding was accomplished using the qualitative data analysis software, Atlas-ti (version 8). As a final step, the conceptual frame obtained from the Grounded Theory analysis was compared to the main concepts that form the basis of TCE to identify similarities and differences, and evaluate its usefulness in moving towards an economic theory of solidarity-based food systems.

\section{Results}

This section begins with descriptions of four individual case study Solawis. In the interest of confidentiality, each Solawi is referred to by a number. The case studies are not intended to provide a representative sample, but rather serve to illustrate the heterogeneity of Solawis. The cases vary (Table 2), especially in terms of the size of the area under cultivation in each operation (from $0.5-5 \mathrm{ha}$ ), the number of shares provided by each (from 40-180), and the annual budget of each Solawi (from 38,000-160,000 euros) (Table 2).

Table 2. Overview of the four Solawi cases.

\begin{tabular}{lcccc}
\hline \multicolumn{1}{c}{ Characteristics } & Solawi $\mathbf{1}$ & Solawi 2 & Solawi 3 & Solawi 4 \\
\hline Area (ha) cultivated in 2018 & 5 & 0.5 & 0.65 & 5 \\
Number of shares *in 2018 & 180 & 40 & 83 & 168 \\
Annual budget for 2018 & 160,000 & 38,000 & 82,000 & 110,000 \\
Target share price/euro in 2018 & 75 & 80 & 75 & 65 \\
Number of delivery stations & 10 & 1 & 3 & 11 \\
Year founded & 2012 & 2014 & 2017 & 2012 \\
Own land & yes & no & no & partially \\
Initiators & Producers & Producer & Consumers & Consumers \\
Production method & Organic not & Organic not & Organic not & Organic certified \\
Legal business form & certified & certified & certified & Sole \\
& Registered & Registered club & Sole proprietorship \\
\hline
\end{tabular}

${ }^{*}$ The number of shares does not equal the number of people benefiting from each share. The number of people behind each share can vary based on household size and living arrangements, and is not known precisely to the producing members. Source: Authors' own compilations.

\subsection{Solawi: Four Case Studies}

The nature of the organizational structure of each Solawi is a result of their unique histories, geographic locations, and the attitudes and characteristics of the members-especially the types and amount of resources (including time and social and financial capital) they possess. The following descriptions provide an account of the founding and development of each Solawi, with emphasis on these factors and how they have contributed to the resulting organizational structures.

\subsubsection{SOLAWI 1}

SOLAWI 1 is located in a small village near a large urban area in the former East Germany. The four founders met at networking events for people seeking to live communally. Due to German laws restricting ownership of land designated as agricultural, the operation was originally founded as a sole proprietorship and the land and subsequent improvements were purchased in the name of the sole proprietor. He and two of the other founders had formally recognized training and previous experience 
in commercial, organic horticulture. The funds to purchase the land and the initial equipment needed for production were obtained through interest-free personal loans from friends and family, and from their own individual inheritances. The original equipment-including two large tractors, an irrigation system and a large hoop house-were obtained from a retiring organic vegetable grower. Therefore, the farm began with some infrastructure; and planting, maintenance and harvest were relatively mechanized from the beginning.

In the first year, the horticulturalists created a budget and calculated the minimum number of paying members required to cover the first year's expenses (for debt payments, seed, young plants, etc.). Due to concerns about obtaining enough paying members, the budget was calculated extremely conservatively. The initial compensation received by the horticulturalists came from unemployment benefits, including start-up funds paid to the sole proprietor. They began the first year of production with 130 shares at an average share price of 55 euros. The calculations for wages in subsequent budgets were based on a 30-h workweek per position, at an hourly rate approximately equal to the German minimum wage.

Despite the formal, legally recognized private ownership of the land and improvements, a set of bylaws for an informal (with no basis in law) cooperative stipulating that the sole proprietor waive all legal rights of ownership was agreed upon by the founding horticulturalists. This document also clearly defined who was responsible for decision-making, the process for collective decision-making and rules for joining and leaving the cooperative. Although the initial exchange relationship in SOLAWI 1 was based on this informal cooperative agreement, the basis for the payment of shares was accomplished through individual contracts between the consuming members and the sole proprietor. These contracts required a contribution of three workdays a year on the farm and a monthly share payment in exchange for each share of the harvest (the total amount harvested divided by the number of shares contracted). The amount of the monthly payment required was based on the principle of solidarity as follows: The budget for the upcoming season (prepared by the team of horticulturalists) was presented to the participants and discussed. The amount required to finance the operation was divided by the number of shares being purchased to determine an average "target" share payment. A bidding round ensued, in which those receiving each share stated how much they were willing and able to pay based on the target payment. If the bids received in the first round totaled to an amount equal to or exceeding the budgeted amount, the process was complete, and each member signed an individual contract reflecting the price he or she had bid. If the budget was not met in the first round, a second bidding round took place.

To formalize the informal cooperative agreement, a registered cooperative-another legal form under German law-was later established. This business form creates a legal person that takes over both the rights and responsibilities associated with the activities of production and distribution, including ownership of assets. Therefore, ownership of the land, the machinery and other improvements has been legally transferred from the original sole proprietor to the cooperative. Eligibility to receive a share in the harvest, to participate in decision-making, and to share ownership in the cooperative's assets, now requires a one-time investment of at least 50 euros (one member, one vote, regardless of amount contributed) in the cooperative.

While the horticulturalists make the day-to-day planning decisions on the farm, the cooperative membership (which includes the horticulturalists) meets monthly. This gives other members a chance to provide input into these decisions, bring up any concerns, help solidify the community feeling, and participate in any formal decisions regarding the cooperative. Formal rules of the cooperative dictate that an agenda including any decisions that are to be made at these meetings are advertised to cooperative members at least a week before the meeting takes place. In order for a decision to be made, a minimum of $5 \%$ of the membership must be present or legally represented, and a three-quarters majority of those present must agree. Despite these formal majority rules, an effort is made to make decisions based on consensus. The horticulturalists interviewed report that $30-40$ members generally attend these meetings. 
Additional community building occurs during the required workdays on the farm where members are provided a meal prepared by and shared with members of the adjacent commune. Smaller groups of consuming members also have the opportunity to form closer ties to one another in the stations to which the horticulturalists deliver the weekly harvest, all of which are located in the nearby urban area. The distribution of the vegetables from the individual delivery stations is self-organized by the consuming members, each of whom is assigned to a particular delivery station upon signing a membership agreement. The amount of vegetables to which each member is entitled is determined by a list the horticulturalists provide of the total amount of each vegetable harvested and distributed that week. Several work groups are organized among the consuming cooperative members. Key among them is the administrative work group, which controls the payments made by consuming members.

Since its founding, SOLAWI 1 has increased the number of shares they provide to the current number of 180, which is the maximum they feel they can supply given the capacity of the operation. The local archdiocese of the protestant church recently approached the Solawi and asked them to cultivate a large piece of church land formerly leased to a conventional grain farmer in order to produce additional vegetables and accommodate more members. The subsequent discussion among the cooperative members during the monthly meetings resulted in the decision not to expand the current operation, as the members feared it would result in a loss of the current community feeling. The original sole proprietor and one of the other horticulturalists have decided to leave their employment in SOLAWI 1 and start a new Solawi operation on the church land. The reasons each gave in separate interviews included the desire to provide the opportunity for Solawi membership to a wider group of people and the responsibility they felt to make sure the nearby church land was cultivated in a socially and environmentally conscious manner.

\subsubsection{SOLAWI 2}

SOLAWI 2 is located near SOLAWI 1. The impetus to begin a Solawi came from the horticulturalist himself, who operates as a sole proprietor. In contrast to SOLAWI 1, the infrastructure at SOLAWI 2 is minimal, and production is almost exclusively accomplished with manual labor. As was originally the case in SOLAWI 1, the central organization exists only as a non-legally binding agreement among members, and individual share contracts are signed between consuming members and the sole proprietor. Here too, the contracts commit members to both a monthly payment for their share in the harvest and participation in workdays at the production site. The amount of this payment is decided through the same budget presentation and bidding process described above, with the budget prepared by the horticulturalist alone. Despite the contractual commitment of the members to contribute labor, the founding horticulturalist (who completed formal training in biodynamic agriculture and subsequently worked at a commercial horticultural operation) reports that most of the work is actually done by him and his life partner. Due to this, the salary he pays himself from the receipts of the sole proprietorship are not commensurate with the number of hours he and his partner work. The land is rented by him as sole proprietor (currently until 2020), and the (minimal) equipment belongs to the horticulturalist as well, rather than being owned collectively. The members of SOLAWI 2 are almost exclusively students, which has led to some issues, in particular, turnover of half of the membership between the last two seasons.

Meetings to which all members are invited are held every three weeks. Planning for these meetings is done by a small, self-organized group of consuming members. In accordance with the document defining the collective agreement, decisions about potential investments to be financed through the monthly Solawi payments or changes in the working procedures are made in these meetings based on consensus. If any member does not agree, he or she has the power to veto a decision, which results in that decision being tabled until the next meeting. Due to previous conflicts, the sole proprietor and a working group of consuming members are currently working on revising the original document. As the tri-weekly meetings are visited sporadically and a different group of people tend to come each time, discussions and decision-making regarding long-term issues are 
difficult. Varying attendance also limits the potential for further development of relationships between consumers and the horticulturalist and among consuming members themselves.

In addition to the communication that takes place during the tri-weekly meetings, the horticulturist sends an information email to the membership list informing them of what is happening on the farm. This serves to keep the group connected and to remind them of the open invitation to help in the field at any time. In addition to these ad hoc opportunities for horticultural work, more formal group work sessions take place at the farm every third Saturday and Sunday in the month. The horticulturist reports that the average turnout for these workdays is about ten members, which tend to be different each time.

Once a week, the vegetables are delivered in bulk to a single location in the nearby urban area with a list of the amount of each vegetable each share should receive. As in SOLAWI 1, organizing distribution of individual shares is the sole responsibility of the consuming members. Until recently, the delivery was also done by the horticulturist. Beginning in 2018, a neighboring vegetable producer who participates in a different Solawi picks up the vegetables and brings them to the location for free.

\subsubsection{SOLAWI 3}

SOLAWI 3 differs from the previous two Solawis in several aspects. SOLAWI 3 is located in a largely rural area in southern Germany situated between two small villages with a combined total population of about 85,000 . Additionally, unlike the previous two Solawis, its founding was driven not from the producer side, but rather from a group of six consumers. This group came together as a result of a local screening of a film about the Solawi concept produced by one of the longest standing Solawis in Germany.

In January 2017, the group found a piece of land on which to start cultivation of vegetables, formed a registered club (a legal form for a voluntary organization under German law), and recruited a horticulturalist. The chair of the Board of Directors (BOD) of the club prepared an initial budget with the assistance of a Solawi Start-up Kit and advice from a consultant-both of which were made available by the German Solawi network. A series of local press articles about their efforts led to an initial member-recruiting event, at which they obtained commitments from enough consuming members to implement the budget and start the first year of production. SOLAWI 3 began their first season in April of 2017 with 47 shares, and by the second season had already increased to 85 shares. This growth resulted in the need to increase production and thus, required the recruitment of a second horticulturist. Both have year-round employment contracts with the club for 30 hours per week at an hourly rate that is above average for horticulturalists in Germany.

As in SOLAWI 1 and 2, a budget is prepared before the beginning of each season and presented to consuming members, and a bidding round determines the amount of individual payments. The budget for the first year was calculated so generously that enough funds remained at the end of the season to purchase a small used tractor. The tractor, an onsite trailer for storage and office use, a donated hoop house, and a hose system for irrigation are, thus far, the only improvements to the rented field, the use of which is governed by a 5-year rental contract between the club and the landowner. The farming equipment and improvements are financed and owned by the club. Due to positive press coverage, a local producer of an organically certified food product approached SOLAWI 3 seeking a project to support to fulfill one of the requirements of organic certification. The company provides an annual monetary donation that covers part of the cost to rent the land and purchase water, but receives no shares and has no voting or decision-making rights. In addition, they donate the labor of their employees in the form of workdays on the farm.

While informal communication takes place on farm workdays, nearly all formal communication between the membership and the horticulturalists is accomplished through the BOD of SOLAWI 3. In the first season, this included a weekly email newsletter sent to the entire membership. The BOD chair estimates that he volunteers a full 8-hour day per week of his own time for organization and communication tasks. Eight self-organized work groups of consuming members accomplish other 
tasks, such as distribution of the produce to and within the delivery locations and special projects designed to protect and promote biodiversity. Whenever necessary, a designated representative of each of those groups reports on the work group's efforts at the biweekly meetings of the BOD.

Decisions about expenditures in excess of 1000 euros and others that are expected to have a large impact on the operation (such as hiring the second horticulturalist) are made at membership meetings, which, at present, are held twice a year. According to the club's bylaws, such meetings must be announced to the entire membership at least two weeks in advance. This announcement must include a detailed agenda, including any items on which a decision must be made. Each member present has one vote, and a simple majority decides the vote. There is no minimum percentage of total membership needed.

In addition to paying their annual membership fee and monthly payments for their harvest shares, consuming members are expected to contribute their labor at workdays at the cultivation site that occur twice each week throughout the growing season. This work is planned and organized by the horticulturalists. All decisions and planning related to planting (including what is grown), harvesting and ordering seeds and young plants are left entirely to the horticulturalists.

\subsubsection{SOLAWI 4}

Like SOLAWIS 1 and 2, the production site for SOLAWI 4 is located in a rural area in the former East Germany adjacent to a large and growing urban area. The evolution of SOLAWI 4 is rather different from that of the other three. The goal of the initial operation was to provide job-training opportunities related to food and agriculture for young people and workers displaced from their jobs due to the end of the former socialist East German state. The sole proprietor of the horticultural operation is a biology teacher in a trade school that specializes in food science, but has no formal training in horticulture or agriculture. Therefore, a formally trained horticulturalist was recruited to supervise the original operation, which produced herbs organically.

The initial 3.5 ha of land used to grow the herbs were purchased (and is still owned by) the sole proprietor. An additional 1.5 ha are rented. However, the daily operations were supported from early on both financially and through the voluntary labor of a group of his friends and colleagues. In 2012, this group of people formed a registered cooperative to collect, hold and distribute their financial contributions to the project. These funds were used primarily to purchase greenhouses that are used by the horticultural operation. Therefore, part of the means of production of the private horticultural operation are owned by the cooperative (and through it, by its members). As time went on, at the request of the members of the cooperative, the operation began to produce organically grown vegetables in addition to the herbs-originally only for the consumption of the members, who paid for them individually. As the herb-growing operation expanded, additional horticulturists were added to the team. Two of the new horticulturists had experience as members of Solawis, and suggested adding this aspect to the business operations. Currently the Solawi aspect of the business constitutes about $70 \%$ of the turnover of the firm, which now has four full-time employees who average $30 \mathrm{~h}$ per week year-round, one apprentice and three part-time helpers for peak planting and harvest times. One of the full-time employees primarily deals with equipment repair and other maintenance tasks, while the other three perform horticultural tasks, city market sales, bookkeeping and communication with the SOLAWI membership. All decisions about horticultural operations (including varieties planted and production methods employed) are discussed in weekly meetings among all full-time employees and the sole proprietor, who ultimately has sole decision-making rights.

SOLAWI 4 is largely self-organized within the 11 distribution stations located in the nearby urban area. While consuming members sign individual contracts with the horticultural operation, individual payments are transferred to a separate account managed by a volunteer at each distribution station who then transfers the total to the operation. The operation delivers the harvest to the delivery stations, but organization of the distribution of shares as well as cleaning and maintenance of the stations is self-organized by consuming members within each delivery station. 
Similar to the other Solawis described here, members are asked to take part in two workdays a year under the supervision of the horticulturalists. Both the horticulturalist interviewed and the sole proprietor report that-while this requires a large amount of organization-production of the vegetables needed to supply the membership would not be possible at the current share price without the additional labor. Much of the member communication takes place during these workdays. When asked about participation, the horticulturalist reported that she interacts directly in the field or greenhouse with approximately 100 members over the course of the season. In addition, a weekly email describing the week's harvest and providing updates on issues and happenings at the production site is prepared by the horticulturalists. Two annual gatherings of the Solawi provide additional communication opportunities, including presentation of the budget for the upcoming season. No bidding round takes place and the share price is fixed at this meeting.

\subsection{Key Concepts Identified in Grounded Theory Analysis}

As illustrated in the prior section, the ways in which Solawis come to be and the ways in which they choose to organize themselves are heterogeneous. Despite the many differences between how individual Solawis organize their operations, a core set of beliefs drive the choice to participate in the Solawi movement, and help determine the organizational structures of individual Solawis. The following is a Grounded Theory-based conceptualized generalization of the results of the in-depth interviews conducted and data collected through participant observation and document analysis. For emphasis, the names of each of the key concepts are presented here in italics.

Solawi participants believe that the world is suffering from a failed system of food production, and that it is not possible to produce quality food in today's agricultural systems and still generate enough income to live a good life. By quality food, Solawistas mean agricultural products about which they have sufficient knowledge to trust that they are produced in compliance with their ideals. Key ideals include social considerations (reasonable working hours, safe and healthy working conditions for agricultural producers and employees); environmental aspects (protection of agri- and biodiversity and water sources, conservative use of fossil fuels); and economic aspects (a good life for agricultural producers, affordability of quality food for people at all socioeconomic levels and all stages of life).

Solawi participants define a good life as having a means of livelihood that (with some degree of certainty) provides basic needs like quality food and shelter, the opportunity to set aside savings for retirement, and other amenities such as vacation time and travel. These goals, however, must be accomplished without having to substantially compromise on the social or ecological ideals involved with providing quality food. To create this life, Solawi participants are seeking a community. This refers less to a geographic location than it does to a mutually supportive social circle, in which individuals share common values such as individual responsibility for stewardship of common resources. Stewardship of common resources entails supporting the creation and preservation of physical and social capital that belongs to all living beings. Because these forms of capital are seen as belonging to the entire collective of living beings, they cannot and should not be appropriated by individual humans based on their purchasing power. This form of community and stewardship is accomplished through the process of de-commodification of food in that its production and distribution are accomplished outside the market mechanism. Therefore, the food produced is decoupled from the monetary compensation received by producers and the perceived monetary value of that food to consumers, as manifested in the price. Instead, emphasis is placed on the collective benefits ensuing from the combined efforts of the Solawi community. 
Solawistas also share the common belief that in order for any collective effort to succeed, self-motivated participation is critical. This means that the most effective motivation for contributing to a group effort comes from the free choice of the individual him- or herself, and therefore, incentives (such as money) or sanctions (such as payments in lieu of required labor inputs) are counterproductive. Through the process of self-motivated participation, individual Solawi participants have the opportunity to undergo a process of self-actualization in that each individual Solawi participant contributes to the group effort in the way that best suits him or her. This freedom of choice allows for the most efficient use of talents and resources within the organization, and also contributes to a process of positive adaptation: Through participation in the production and distribution of their own food, consuming members develop an appreciation and understanding of the amount of resources, skill and knowledge required to produce quality food, and a closer connection to the land, water, plants and animals (and the foods they provide). In turn, producers gain a better understanding of consuming members, their fears and concerns about the way their food is produced, and the tradeoffs they are willing to accept in its production.

There is a pronounced emphasis on the process of information exchange as a method of strengthening the bonds among participants and generally, moving the entire community towards their common goals. The open door of Solawi producers assures each consuming member that he or she is always welcome to visit the field and work alongside the horticulturalists, to ask questions about how or why things are done, and to express concerns or make suggestions for improvement. Both processes are facilitated by the highly communicative nature of Solawi participants. This manifests itself not only as a willingness, but as a personal need to discuss details of production and organization with fellow Solawi participants. The reasons behind decisions are made explicit, and the opinions of all participants are considered in frequent interactions that occur in the field during workdays, at member meetings, at food distribution locations, and through regular email newsletters.

Hence, the success of individual Solawis depends on these processes to create a sense of mutual trustworthiness in both participating consumers and producers. Mutual trustworthiness allows producing members to make use of resources that, in legal terms, are the personal property of consuming members. At the same time, it allows consuming members the freedom to decide when and where to make additional individual contributions of personal resources (including time and skills) without the need for coordination from above or formal controls. The result is a feeling of inclusiveness of the Solawi network and the individual Solawi communities. Insistence on restrictive formal rules is seen as having the potential to exclude individuals or groups of people who might choose other, equally legitimate ways of creating and participating in solidarity-based exchange arrangements.

As a result of the processes described above, consuming members develop a sense of identification-a feeling of ownership and belonging to the operation and the community that supports it. Through their involvement in creating and implementing both formal and informal structures of ownership, decision-making and distribution of work, members begin to feel that the operation and the associated risks responsibilities and benefits belong to them. The Solawi model also provides consuming members with a personification of the operation and the producers through personal experience of the changing seasons in the operation. They witness the different types of work that take place in those seasons and the different foods that are produced. Therefore, the food takes on the attributes the consumer associates with the place and processes of production as well as with the entire Solawi community. The community exercises normative pressure on all involved to participate in the collective effort and to do one's best to support a positive experience within the community, and a positive image of the community to the outside. 


\section{Discussion}

Most of the key concepts identified in the Grounded Theory analysis reflect the basic tenets upon which TCE theory is built (Figure 1). In his explanation of why extra-market institutions for governing exchange (firms) exist at all Coase stated, "the distinguishing mark of the firm is the supersession of the price mechanism" [24] (p. 389). This is mirrored by the emphasis Solawistas' place on the importance of the de-commodification of food, which is reflected in the organizational structures they create. This is best represented by their adoption of Williamson's concept of economizing on transaction costs through the internalization of downstream steps [10]. Rather than functioning as individual actors in a free market, participants (both producers and consumers) are seeking a community in which they assume various roles in loosely defined internal divisions of a hybrid organizational structure (neither market nor firm) [18].

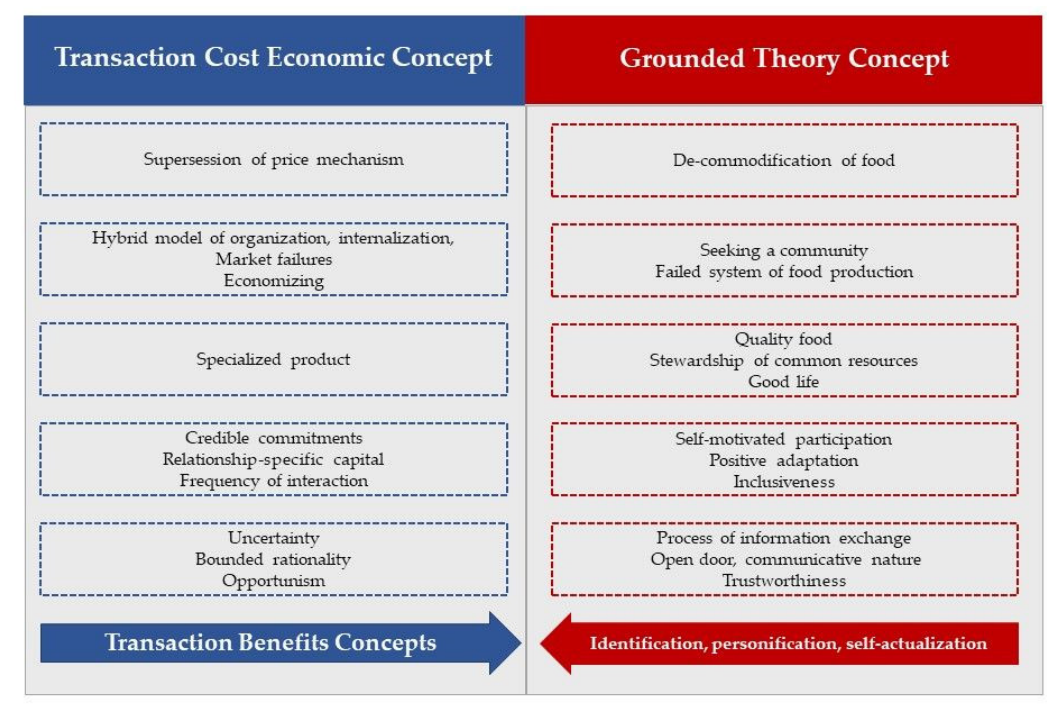

Figure 1. Schematic of relationships between concepts from Transaction Cost Economics (TCE), the Grounded Theory developed and Transaction Benefits. Source: Authors' own elaboration based on TCE [10-16,24-26].

Solawistas perception of the need to create new organizational structures due to the failed system of food production substantiates Williamson's discussion of market failures as the justification for internalization in situations where buyers require specialized products [10]. Again, the specialized product Solawistas cannot find in the market is quality food, which requires stewardship of common resources and guarantees a good life for producers (Figure 1).

The self-motivated participation of members in contributing personal resources to the collective effort can be conceived as making credible commitments through the creation of relationship-specific capital in the sense discussed in the TCE literature [12]. A similar situation exists from the producer side in that several of the Solawis described have evolved to create organizational structures that formalize ownership of physical capital dedicated to the Solawi community through the establishment of registered clubs and cooperatives.

The open door of the producers satisfies not only the communicative nature of participants, but serves as a protection from fears of opportunism due to the problems of bounded rationality and access to information, and helps overcome uncertainty (Figure 1). On the side of consuming members, mutual trustworthiness helps limit the search costs involved with finding producers who are capable of and willing to provide the type of specialized product (quality food) they wish to purchase. On the producer side, the process of information exchange allows them to better understand the exact nature of the quality food consumers seek; once again, limiting uncertainty and associated transaction costs. In addition, it provides them the opportunity to take advantage of the positive adaptation process inherent to the 
Solawi model to help consuming members of Solawis understand what quality food means from the side of the producer (Figure 1). This again serves an economizing function, as it eliminates the need for more formal and costly forms of control, such as external certification.

All membership agreements of the four Solawis described above include provisions that each consuming member perform duties that support the group effort in addition to making regular financial contributions: Typically, though, a core group of people contributes a substantial amount of time, and some do not seem to do so at all. In addition, all reported that the performance of these duties by the membership is essential (in either financial or organizational terms) to the successful operation of individual Solawis. Nevertheless, none of these Solawis issues formal sanctions in the case of shirking, due to their belief in the importance of self-motivated participation. This, and the dependence of the success of the Solawi model on the communicative nature of participants, could limit the potential for its implementation among participants who do not share these beliefs and characteristics.

Therefore, many of the key elements of TCE are captured in the basic philosophies of Solawi participants, and reflected in the organizational structures of individual Solawis (Figure 1). Still, despite its difference from neoclassical economic thought, some proponents of TCE purport that, "[g]iven the gains to be derived from trade, each party will wish to arrange the terms of trade in such a way as to appropriate for himself as large a share of those gains as possible" [15] (p. 175). The results of the Grounded Theory analysis suggest that Solawi participants are more interested in creating value for the entire Solawi community and taking personal responsibility for stewardship of common resources than in maximizing personal economic gain. As shown, this concept has significant implications for the ways in which production and distribution are organized due to the core set of beliefs Solawistas share, e.g., a good life, quality food, inclusiveness, stewardship of common resources and self-motivated participation.

Many of the benefits that members and producers attribute to Solawi arrangements are non-tangible, such as self-actualization, identification and personification (Figure 1). Although participants are able to enjoy these benefits as a direct result of contributing personal resources (skills and labor) to the collective effort, they do not seem to see these contributions as costs, largely due to the emphasis they place on self-motivated participation. This suggests that a valuable addition to TCE could be the inclusion of the concept of transaction benefits (Figure 1) to represent less tangible, accumulated value. The concept of transaction benefits has been introduced elsewhere; for example, Blomqvist, et al. [25] explored the idea in the context of the decision to create partnership agreements in the electronics industry that seem to be inefficient in transaction cost terms. The authors posited that where trust and uncertainty are both highly relevant, such seemingly inefficient arrangements generate non-monetary value-for instance in the form of tacit knowledge about customer needs which helps deter competition from new entrants. New entrants may attempt to capitalize on Solawi brand recognition to recruit members of existing Solawis by offering lower prices for products that bear the Solawi name, but do not follow the Solawi principles. This is analogous to the findings in the French wine industry discussed above [18].

Zajac and Olsen identify "two major limiting emphases in standard transaction cost analysis" [26] (p. 133). The first is TCE's focus on cost minimization for a single party to an exchange, due to its inherent "neglect of the interdependence between exchange partners" [26] (p. 132). The second is its focus on the structural characteristics of organizations rather than on the processes through which these structures come to be and adapt over time. These processes create value despite the resources they consume. They serve to strengthen the relationships between exchange partners through the learning processes they go through together. This helps shape the development of the organizational partnership and increases its ability to adapt. One of the key concepts identified in the Grounded Theory analysis-the self-actualization process-is directly related to this learning and development process. The process of positive adaptation that takes place through the frequent interactions among Solawi participants is key to the transformative potential of Solawi. As is evidenced by the individual histories of each of the Solawis described, the organizational structures they create continue to evolve 
in order to strengthen the bonds between consuming and producing members and ensure the integrity of the Solawi product.

Each Solawi can be seen as a set of interrelated organizations, whether formal (as in a sole proprietorship, registered club or cooperative) or informal (as in groups of consuming members organized at the level of the delivery stations). As these Solawis mature and increase in size, the structures they create tend to become increasingly complex. In TCE terms, these increasingly complex arrangements may be inefficient considering the amount of coordination they require (and thus, the amount of resources they consume). The transaction benefits concept helps explain these choices.

\section{Conclusions}

The heterogeneity of the organizational structures of individual Solawis is made possible by the loose organizational structure of the Solawi network. Due to the success of the Solawi concept, new Solawis are forming that follow practices that many participants feel are not in keeping with Solawi principles. This could reduce the effectiveness of the Solawi model for creating sustainable positive change for Solawi participants as well as in the wider system of food production, distribution and consumption. The question of how to deal with this and still allow individual Solawis to create organizational structures that meet their individual needs and environments is debated within individual Solawis and at the network level. Some feel that developing stronger controls (similar to a certification system) is necessary, while others see this as unnecessarily costly and contradictory to their views regarding tolerance of diversity and freedom of individual choice.

The analysis of individual Solawis and the Solawi network has shown that neoclassical ideas of profit maximization and dichotomous relationships between buyers and sellers are not sufficient to understand the decisions of actors in alternative food networks. The distinction between producer and consumer is intentionally blurred in these networks, and other non-monetary benefits are equally as important as the cost savings realized through internalization of production and distribution steps. Focusing on the processes through which relationship partners iteratively reconfigure the rules and norms that govern their interactions has the potential to help form a more viable theory to help better understand alternative economic arrangements.

With the addition of the concept of transaction benefits, the focus of TCE on organizational structure has particular relevance for evaluating the potential for Solawi organizations to expand in size. Individual Solawistas are beginning to ask these questions themselves. They recognize that their own capacity to communicate effectively within their Solawi community, and maintain the trust necessary to retain existing and recruit replacement members is limited. This is illustrated by the decision of SOLAWI 1 not to expand its operations. This limit to growth may have implications for the effectiveness of the Solawi concept in the long-term as a means for widespread provision of agricultural products. The struggle within the Solawi network to decide to what extent to limit the ways, in which Solawis are 'allowed' to operate under the Solawi name and still maintain Solawi standards has similar implications.

The freedom to innovate and to structure Solawis to meet the desires of the individuals involved also provides a great deal of adaptability to changing external forces. Potential new regulations on how agricultural products are produced at the country or European Union (EU) levels, or attempts by retailers to coopt the solidarity principle for their own benefit could render the Solawi difference less relevant. This would not necessarily have negative economic consequences for producers in general, but might remove the most powerful incentives producers have to participate in Solawis. Therefore, potential negative implications would be more relevant for consumers who might then be deprived of the transaction benefits they derive from Solawi participation. These considerations need to be taken into account when devising or revising regulations regarding the production of agricultural products or providing government incentives designed to promote the formation of solidarity-based food systems. 
The authors acknowledge the focus on Solawi producers when deciding whom to interview for this research. Further qualitative research focusing more on the consumption side could help provide a more complete picture of the Solawi experience-particularly in relationship to the concept of transaction benefits. As in-depth interviews of individuals are time-consuming and do not necessarily capture group dynamics most effectively, future research using other methods of data collection might add to or challenge the concepts identified here. Roundtable discussions among consuming members of different Solawis or more interactive methods of engaging participants, such as those used in participatory action research are possible means to this end.

Additional potential avenues for further research are indicated by the involvement of outside institutions, such as churches and other businesses in supporting the individual Solawis examined here. Social Network Analysis designed to identify and quantify the relationships of individual Solawis to the communities in which they are based could also help explain differential levels of resources available to them through their members and their social ties.

Author Contributions: Conceptualization, L.A.C. and V.B.; Data curation, L.A.C.; Formal analysis, L.A.C.; Investigation, L.A.C.; Methodology, L.A.C. and V.B.; Project administration, L.A.C.; Resources, V.B.; Supervision, V.B.; Validation, L.A.C. and V.B.; Visualization, L.A.C. and V.B.; Writing-first draft, L.A.C.; Writing-review \& editing, L.A.C. and V.B.

Funding: No outside funding was used to support this research.

Acknowledgments: The authors wish to acknowledge the extensive time contributed by the interviewees as well as the helpful comments of three anonymous reviewers.

Conflicts of Interest: The authors declare no conflicts of interest. 


\section{Appendix A}

Table A1. Example of conceptual coding of the concept communicative nature with examples of data from different sources.

\begin{tabular}{|c|c|c|c|}
\hline Code & Code Definition & Data Type & Data Excerpt ${ }^{*}$ \\
\hline \multirow[t]{5}{*}{$\begin{array}{l}\text { Communication between producers and } \\
\text { consumers }\end{array}$} & \multirow[t]{5}{*}{$\begin{array}{l}\text { Producing members must be willing and able to } \\
\text { communicate with members at all times (e.g., site visits, } \\
\text { workdays, formal and informal meetings); producing } \\
\text { members who enjoy the communication with other members } \\
\text { will do better with the Solawi concept than those who do not. }\end{array}$} & Direct quote from in-depth interview & $\begin{array}{l}\text { "I never wanted to sit on my plot of dirt by myself and work along }[\ldots .] \text {. You } \\
\text { have to be the type for Solawi and I believe that many farmers they rather like } \\
\text { sitting on their plot of dirt. They do not need that [amount of communication]" } \\
\text { (Producer Solawi 2). }\end{array}$ \\
\hline & & Direct quote from in-depth interview & $\begin{array}{l}\text { "There are farmers who are able to talk and who want to talk. Then they can do it } \\
\text { themselves, if they have enough time. There are many who say, well I would } \\
\text { prefer to sit on the tractor and milk my cows, and all that talking can be done by } \\
\text { somebody else. They should delegate. [...] In each Solawi there are people who } \\
\text { like to do the communication, and they must do it" (Solawi consultant). }\end{array}$ \\
\hline & & Direct quote from in-depth interview & $\begin{array}{l}\text { "He says he is all alone from morning to nightfall. His wife goes to work } \\
\text { somewhere and he wants communication. He wants people around him who } \\
\text { support him" (Consuming member/Co-founder Solawi 3). }\end{array}$ \\
\hline & & Excerpt from field notes & "Solawi is pure communication" (Producer Solawi 2). \\
\hline & & Excerpt from archival materials & $\begin{array}{l}\text { "We are looking for somebody who enjoys working independently as well as in a } \\
\text { team and enjoys sharing knowledge and accumulated experiences with Solawi } \\
\text { members" (Vacancy announcement for Solawi producer in Solawi network } \\
\text { newsletter). }\end{array}$ \\
\hline \multirow[t]{4}{*}{$\begin{array}{l}\text { Consumers communicating among } \\
\text { each other }\end{array}$} & \multirow{4}{*}{$\begin{array}{l}\text { The process of communication among consumers; learning } \\
\text { from one another, developing personal relationships; } \\
\text { developing an understanding of the personal situations of } \\
\text { fellow members, helps in understanding the extent to which } \\
\text { self-motivated participation is possible; takes place in } \\
\text { self-organized distribution stations, self-organized work } \\
\text { groups to perform specific Solawi tasks, exchange of recipes } \\
\text { and photos of group activities on the website, at workdays in } \\
\text { the field, at membership meetings and other group activities; } \\
\text { serves to develop trustworthiness and contributes to } \\
\text { inclusiveness. }\end{array}$} & Direct quote from in-depth interview & $\begin{array}{l}\text { "This is what we have here now in [the meetings of the network for] solidarity } \\
\text { agriculture, and that is why I Iheve this ear on me [points to sticker on his shirt], } \\
\text { there are people who see, have the feeling 'what is going on here?' And in } \\
\text { communities you notice very often that what is talked about, is not what is really } \\
\text { lived [refers to his function as a listening ear, e.g., for newcomers, and that issues } \\
\text { are not necessarily addressed directly]" (Solawi consultant). }\end{array}$ \\
\hline & & Direct quote from in-depth interview & $\begin{array}{l}\text { "For example, a work group formed for knitting. I thought, what does this have } \\
\text { to do with solawi? But in the work group there are sometimes } 15 \text { women [since } \\
\text { the interview a man has also joined] who go to the home of one woman, and a lot } \\
\text { is chatted about there, and that is positive. They do not just chat about many } \\
\text { things, but also about Solawi, and they get to know each other and that is a good } \\
\text { thing" (Consuming member/Co-founder Solawi 3). }\end{array}$ \\
\hline & & Excerpt from field notes & $\begin{array}{l}\text { Two-hour workshop organized by work group of consuming members to discuss } \\
\text { the topic of 'solidarity'; } 40-45 \text { attendees ( } 30 \% \text { men, } 70 \% \text { women); three rotating } \\
\text { discussion groups with the following themes: (1) having a say, }(2) \text { needs and } \\
\text { expectations, (3) meaning of solidarity. All members present participated in each } \\
\text { work group. Each had a turn to speak, but could pass if they wished. Responses } \\
\text { were gathered on a flipchart. And presented to the entire group in the final } \\
\text { session (Membership meeting / workshop Solawi 3). }\end{array}$ \\
\hline & & Excerpt from archival materials & $\begin{array}{l}\text { "Awareness raising and development of new ideas, new topics, new paths - } \\
\text { discussion, dealing with topics that move us. Promote communication within the } \\
\text { group, promote contacts among members, work groups, support the board of } \\
\text { directors and move them to action" (Website Solawi 3: description of } \\
\text { self-organized work group of members). }\end{array}$ \\
\hline
\end{tabular}

* All excerpts have been translated by the authors into English (from German). Source: Authors' own elaborations. 


\section{Appendix B Interview Guide}

\section{Questions discussed with all interviewees}

Introductory: Please explain a bit about yourself-what is your education, previous involvement with agriculture, current occupation and family situation.

Please explain how and when you came to be involved in the Solawi/Solawi network. What factors contributed to your decision to become involved with/found your Solawi?

How would you describe your role in your Solawi/in the Solawi network? Do you receive monetary compensation for your involvement in your Solawi/the Solawi network? If so, what is your relationship (nature of contract) to the Solawi/Solawi network?

At the end of each interview: Is there anything you would like to add that you feel is important to know that we have not yet discussed?

\section{Questions discussed with participants in individual Solawis}

How did the membership of the Solawi come together? How has the membership changed over time in number, type of participants? How many members (both producing and consuming) are there in your Solawi?

Are there participants who receive monetary compensation for their work in your Solawi? If so, how much, how many hours do they work, what is the nature of the work contract, who is the employer?

Please briefly describe the organizational structure of your Solawi. What is the ownership structure (legal business form, decision-making rights and procedures, ownership/rental agreements for physical capital and land)? What are the means for communication among members?

Please describe the physical characteristics of your Solawi. Please tell me about size and location of production site(s); previous history of production site(s) if known; methods of production, e.g., use of chemical inputs, use of machinery; method and site of distribution; relationship of site to consumer population, e.g., distance, ease of access.

Please describe the individual contracts for receiving Solawi shares. How are responsibilities for production/distribution/communication divided among members? Are there minimum requirements for contributing financial resources/time/other resources? Are there procedures for sanctioning members who do not contribute the minimum?

What particular benefits to you personally receive from Solawi participation? What would you say are the main reasons that other members of your Solawi choose to participate? What would you say were/are the biggest challenges you personally/the group faced(s) in forming and running it?

\section{Questions discussed with Solawi consultants}

Can you characterize the producers you have encountered in your consultancy work in terms of age, educational level, specific interests or abilities, work and life history? Would you say that most have shown interest in becoming involved/founding a Solawi due to personal belief in the Solawi idea (as defined by the Solawi network) or more as a potential means to ensure survival of an existing operation?

Have you consulted with producers/groups of consumers who you have advised NOT to form/participate in a Solawi? If so, why?

Source: Authors' own elaborations 


\section{References}

1. Kneafsey, M.; Venn, L.; Schmutz, U.; Balázs, B.; Trenchard, L.; Eyden-Wood, T.; Bos, E.; Sutton, G.; Blackett, M. Short Food Supply Chains and Local Food Systems in the EU. A State of Play of their Socio-Economic Characteristics; Joint Research Centre Institute for Prospective Technological Studies, European Commission: Seville, Spain, 2013.

2. Berti, G.; Mulligan, C. Competitiveness of small farms and innovative food supply chains: The role of food hubs in creating sustainable regional and local food systems. Sustainability 2016, 8, 616. [CrossRef]

3. Bitsch, V. Sustainability as innovation: Challenges and perspectives in measurement and implementation. In Diffusion and Transfer of Knowledge in Agriculture; Huyghe, C., Bergeret, P., Svedin, U., Eds.; Quae: Cedex, France, 2016; pp. 15-20. Available online: www.quae.com/fr/r5038-diffusion-and-transfer-of-knowledgein-agriculture.html (accessed on 1 December 2018).

4. Moulaert, F.; Ailenei, O. Social Economy, Third Sector and Solidarity Relations: A Conceptual Synthesis from History to Present. Urban Stud. 2005, 42, 2037-2053. [CrossRef]

5. Voß, E. Wegweiser Solidarische Ökonomie: Anders wirtschaften ist möglich! AG SPAK: Neu-Ulm, Germany, 2010. Available online: https: / / www.amazon.de/Wegweiser-Solidarische-\%C3\%96konomie-Wirtschaften-m\% C3\%B6glich/dp/3930830507 (accessed on 1 December 2018).

6. Kondoh, K. The alternative food movement in Japan: Challenges, limits, and resilience of the teikei system. Agric. Hum. Value 2015, 32, 143-153. [CrossRef]

7. Brown, C.; Miller, S. The impacts of local markets: A review of research on farmers markets and community supported agriculture (CSA). Am. J. Agric. Econ. 2008, 90, 1298-1302. [CrossRef]

8. Blättel-Mink, B.; Boddenberg, M.; Gunkel, L.; Schmitz, S.; Vaessen, F. Beyond the market-New practices of supply in times of crisis: The example community-supported agriculture. Int. J. Consum. Stud. 2017, 41, 415-421. [CrossRef]

9. Seyfang, G. Ecological citizenship and sustainable consumption: Examining local organic food networks. J. Rural Stud. 2006, 22, 383-395. [CrossRef]

10. Williamson, O.E. The vertical integration of production: Market failure considerations. Am. Econ. Rev. 1971, 61, 112-123.

11. Williamson, O.E. Strategizing, economizing and economic organization. Strateg. Manag. J. 1991, 12, 75-94. [CrossRef]

12. O'Donnell, E. Where are we now and where do we go from here? A review of the transaction cost-based buyer-seller relationship literature. Mark. Manag. J. 2009, 19, 18-32.

13. Ménard, C.; Valceschini, E. New institutions for governing the agri-food industry. Eur. Rev. Agric. Econ. 2005, 32, 421-440. [CrossRef]

14. Williamson, O.E. Hierarchies and markets. Int. Encycl. Soc. Behav. Sci. 2001, 10, 6690-6693.

15. Masten, S. Transaction-cost economics and the organization of agricultural transactions. In Industrial Organization; Emerald Group Publishing Limited: Bingley, UK, 2015; pp. 173-195.

16. Williamson, O.E. Credible commitments: Using hostages to support exchange. Am. Econ. Rev. 1983, 73, 519-540.

17. Hagedorn, K. Post-Socialist farmers' cooperatives in Central and Eastern Europe. Ann. Public Coop. Econ. 2014, 85, 555-577. [CrossRef]

18. Traversac, J.B.; Rousset, S.; Perrier-Cornet, P. Farm resources, transaction costs and forward integration in agriculture: Evidence from French wine producers. Food Policy 2011, 36, 839-847. [CrossRef]

19. Netzwerk Solidarische Landwirtschaft Home Page. Available online: https://www.solidarischelandwirtschaft.org/index.php?id=92 (accessed on 15 October 2018).

20. Raynolds, L.T. Re-embedding global agriculture: The international organic and fair trade movements. Agric. Hum. Values 2000, 17, 297-309. [CrossRef]

21. Busa, J.; King, L. Corporate takeover? Ideological heterogeneity, individualization, and materiality in the corporatization of three environment-related movements. J. Environ. Stud. Sci. 2015, 5, 251-261. [CrossRef]

22. Bitsch, V. Qualitative research: A grounded theory example and evaluation criteria. J. Agribus. 2005, 23, 75-91.

23. Corbin, J.; Strauss, A. Grounded theory research: Procedures, canons, and evaluative criteria. Qual. Sociol. 1990, 13, 3-21. [CrossRef] 
24. Coase, R.H. The nature of the firm. Economica 1937, 4, 386-405. [CrossRef]

25. Blomqvist, K.; Kyläheiko, K.; Virolainen, V.M. Filling a gap in traditional transaction cost economics: Towards transaction benefits-based analysis. Int. J. Prod. Econ. 2002, 79, 1-14. [CrossRef]

26. Zajac, E.J.; Olsen, C.P. From transaction cost to transactional value analysis: Implications for the study of interorganizational strategies. J. Manag. Stud. 1993, 30, 131-145. [CrossRef]

(C) 2019 by the authors. Licensee MDPI, Basel, Switzerland. This article is an open access article distributed under the terms and conditions of the Creative Commons Attribution (CC BY) license (http:/ / creativecommons.org/licenses/by/4.0/). 